\title{
Evaluation of the Functional Properties of Prosopis juliflora Protein Concentrate Obtained by Different Methods
}

\author{
Jose Jaimes-Morales $^{1}$, Annie Acosta-Delgado ${ }^{2}$, Carlos Severiche-Sierra ${ }^{3}$, Yesid Marrugo-Ligardo ${ }^{4}$, \\ Elias Bedoya-Marrugo ${ }^{5}$ \\ "Universidad de Cartagena, MAAS Research Group on Environment, \\ Food and Health. Cartagena de Indias, Bolivar, Colombia. \\ 1jjaimesm@unicartagena.edu.com \\ 2aacosta2@unicartagena.edu.co \\ ${ }^{3}$ cseveriches@gmail.com \\ 4ymarrugol@unicartagena.edu.co \\ *University Foundation Technological Comfenalco, CIPTEC Research Group. \\ 5 ebedoya@tecnologicocomfenalco.edu.co \\ 3 cseveriche@tecnocomfenalco.edu.co
}

\begin{abstract}
The functional properties of Trupillo protein concentrate (Prosopis juliflora) obtained by different methods for its possible use as a food ingredient were evaluated. Determining the bromatological properties of the flour obtained from the seeds of Trupillo (Prosopis juliflora), the functional properties and the in vitro digestibility of the protein concentrates. Protein concentrates were obtained by isoelectric point methods, hydroalcoholic solutions and a combination of both. The different functional properties were evaluated as; Lipid Adsorption Index (IAL), Water Retention Capacity (CRA), Apparent Density (DA), Swelling Capacity (CH), Foam Expansion Capability (CEE), Foam Density (DE), Stability (EE), Emulsifying Capacity (CE). Protein concentrates obtained by isoelectric point, hydroalcoholic solutions and a combination of both presented protein content of $73.33 \pm 0.58,68.67$ $\pm 1.53,78.33 \pm 0.58$ respectively. The composition of all the concentrates was consistent with that reported in the literature. In addition, alcohol precipitation had a better lipid retention capacity and (C.E). This protein ability is particularly important in the production of shaken products and emulsified sauces such as mayonnaise, frozen desserts and sausages.
\end{abstract}

Keyword- Food ingredient, Hydroalcoholic solutions, Isoelectric point, Legumes, Protein concentrate.

\section{INTRODUCTION}

Starch Legumes are now a major source of human nutrition, especially among the low-income population of developing countries [1]. Of the most relevant for human consumption we have soybeans, beans, chickpeas, lentils, peanuts, beans and peas [2]. The potential protein seeds, legumes have increased their importance in the food industry as ingredients in dietary nutritional formulas and emulsified [3] products. Protein Protein Products (PPVs) according to the Codex Alimentarius (1995) [4], which can be classified according to their protein percentage in: protein meals (50-65\%), protein concentrates (65-90\%) And protein isolates (>90\%).

Protein concentrate is called that food product obtained from flours of vegetable and animal origin. These meals has high protein content them through a series of causing a foodstuff with less fat, higher protein content and an acceptable nutritional and economic value treatments [2]. However, the successful use of PPVs in food formulation depends on their functional properties [5]. Properties consisting of the water and oil absorption index, the emulsifying and foaming capacity, the foam and emulsion stability, gelation capacity and protein solubility, which have been studied in different species of legume $[6,7]$.and at different percentages of protein concentration $[8,9,10]$.

The importance of these properties varies with the type of food products in which the protein concentrate is used. For example, high oil and water binding proteins were desirable for use in meats, sausages, bread and cakes, while proteins with high emulsifying and foaming properties were good for salads, sausages, mortadella, Soups, sweets, desserts and frozen cakes. The methods used for the development of plant protein concentrate include isoelectric precipitation, alcohol precipitation and isoelectric precipitation with alcohol precipitation [11].

Thus, the development of a protein concentrate from the trill flour could provide the food industry with a novel food ingredient for the formulation of products. The latter is critically necessary in many developing countries, because animal protein is more expensive and is increasingly beyond the reach of many people in underdeveloped countries. The limited information available in the literature on flour protein concentrates of trupillo seeds (Prosopis juliflora) makes the purpose of this study was to obtain different preparations and to determine the functional properties of protein concentrates in order to infer their possible Use by the food 
industry. In this work the general objective was to evaluate the functional properties of Trupillo protein concentrate (Prosopis juliflora) obtained by different methods for its possible use as a food ingredient. In detail, the specific objectives were to obtain the Trupillo flour (Prosopis juliflora), then to determine the bromatological content of the Trupillo flour, as well as to evaluate the anti nutritional factors present in the flour and finally To determine and evaluate the functional properties of the concentrate Protein obtained by the different methods. Proteins in order to infer their possible use by the food industry.

\section{EXPERIMENTAL}

\section{Selection of seed samples from Trupillo}

For the development of this research, seeds of Trupillo (Prosopis juliflora) in good sanitary phytosanitary conditions were taken as the study universe. The seeds were extracted from the legumes harvested around Cerro de La Popa (Cartagena de indias, Bolívar-Colombia).

\section{Operations for the production of flour from Trupillo}

Classification: Yellow Trupillo pods were selected according to the degree of good hygienic phytosanitary conditions, to obtain the seeds and later of the flour.

Milling: The seeds were ground in a hammer mill.

Sieving: Sieve number 40 was used in order to achieve a finer and more homogeneous material.

\section{Physicochemical and bromatological characterization of flour}

In this second stage the physicochemical characterization of the flour was carried out. $\mathrm{pH}, \%$ moisture, ash, protein content and fat content were determined in triplicate.

\section{Quantification of anti-nutritional factors present in Trupillo flour}

To establish the anti-nutrient content, the amount of phenols and tannins present in the flour obtained was determined [12]. The analyzes were done in triplicate, as did Severiche et al. (2013) [13].

\section{Preparation of the protein concentrate from the flour of Trupillo}

a) Isoelectric precipitation (recovery of extracted proteins) [14].

b) Precipitation with hydroalcoholic solutions $[15,16]$.

c) Isoelectric precipitation and precipitation with alcohol [16].

\section{Determination of proteins by the Kjeldahl method to the concentrate obtained from Trupillo}

The protein content was used a methodology similar to that described previously.

\section{Determination of the functional properties of the protein concentrate of Trupillo}

For the determination of the following parameters we used the established in the investigation of Marrugo et al. (2007) [17].

Index of Adsorption of Lipids (I.A.L.)

Water Retention Capacity (C.R.A.)

Apparent Density (D.A.)

Emulsifying capacity

Swelling Capacity (C.H.)

Foam expansion capacity (C.E.E.)

Density of Foam (D.E.)

Stability of Foam (E.E.)

Performing in vitro digestibility tests on Trupillo's concentrate to verify the actual utilization capacity of the organism

The process for the determination of the digestibility coefficient will be developed according to the protocol of Miranda et al. (2013) [18] according to AOAC 1990 [19].

Statistic analysis.

Results from three independent trials were expressed as the mean \pm standard error of the mean (ESM) and analyzed by one-way variance analysis (ANOVA), followed by Tukey tests for multiple comparisons. Values of $\mathrm{P}<0.05$ were considered significant. 


\section{III.RESULTS AND DISCUSSION}

\section{Physicochemical and bromatological characterization of flour}

In Table 1, the results corresponding to the proximal composition of the Trupillo (Prosopis juliflora) are presented. The values between $8.9 \%$ of humidity and $4.87 \%$ of ash within the ranges reported by other authors of $8.12 \%$ and $4.85 \%$ respectively [7, 20], lipid and protein results are also similar to those reported by Jaimes et al. (2014) [3].

TABLE I. Bromatological analyzes of flour

\begin{tabular}{|l|l|}
\hline $\mathrm{pH}$ & $5,87 \pm 0,03$ \\
\hline Humidity \% & $8,90 \pm 0,36$ \\
\hline Ash $\%$ & $4,87 \pm 0,32$ \\
\hline Proteins\% & $37,67 \pm 2,52$ \\
\hline Lipids\% & $8,100 \pm 0,10$ \\
\hline
\end{tabular}

\section{Quantification of antinutritional factors present in flour}

Table 2 shows the content of phenols in the flour of the seeds of Trupillo is comparable to that obtained in other legumes such as Pisum sativum $(0.3 \%)$, Cassia floribunda $(0,41 \%)$, C. obtusifolia $(0,66 \%)$ and Phaseolus vulgaris L., 0.26-0.37\%\% phenol levels comparable with the study by Chaparro (2009) [21].

As a quantified tannin content, the flour presents a similar value of tannins to that obtained by Chaparro (2009) [21] in M. deeringiana 2.19\%. This value is high compared to that reported for Phaseolus vulgaris L., $0.15 \%$ and other legumes $(0.3-1.56 \%)$ [21]. The tannins are mainly concentrated in the seed shell, therefore, the sieving could decrease its concentration.

Table II. Antinutritional factors present in the flour

\begin{tabular}{|c|c|}
\hline Total phenols & $0,07 \pm 0,01$ \\
\hline Tannins & $2,20 \pm 0,09$ \\
\hline
\end{tabular}

Values correspond to mean of three replicates $+/$ - standard deviation

Percent protein of Trupillo's protein concentrate by the isoelectric point, hydroalcoholic solutions, isoelectric point and alcohol

The protein content of the protein concentrates is shown in Table 3, the highest protein content, it has isoelectric precipitation with alcohol precipitation and the lowest protein content is precipitated with alcohol. The protein content obtained was within a range similar to that described by Wu et al. (2009) [16] ranging from 69-72\% protein on dry basis.

The percentage of ethanol used is critical, since if it is low the denaturation of the proteins increases, the alcohol is more difficult to recover by distillation and the drying of the concentrate becomes more complicated. On the contrary, with very high percentages of ethanol, the extraction of sugars is insufficient $[1,3]$.

Table III. Percentage of Protein Concentrate of Trupillo by the isoelectric point, hydroalcoholic solutions, isoelectric point and alcohol

\begin{tabular}{|l|l|}
\hline Isoelectric point & $73,33 \pm 0,58$ \\
\hline Hydroalcoholic solutions & $68,67 \pm 1,53$ \\
\hline Isoelectric point and alcohol & $78,33 \pm 0,58$ \\
\hline
\end{tabular}

Values correspond to mean of three replicates $+/$ - standard deviation

Determination of the functional properties of the protein concentrate of Trupillo by the isoelectric point, hydroalcoholic solutions and isoelectric point and alcohol

In Table 4, we find the functional properties of the protein concentrates of Trupillo obtained by the different methods. The capacity of oil absorption is the product of physical entrapment of fats by proteins, through the formation of structures called micelles. This ability is determined by the structure of the protein matrix and the arrangement of amino acids within the structure, which in turn determines the hydrophobic protein-fat interactions [3]. 
Table IV. Functional properties of the protein concentrate of trupillo by the isoelectric point, hydroalcoholic solutions, isoelectric point and alcohol

\begin{tabular}{|l|l|l|l|}
\hline Functional property & Isoelectric point & $\begin{array}{l}\text { Hydroalcoholic } \\
\text { solutions }\end{array}$ & $\begin{array}{l}\text { Isoelectric point and } \\
\text { alcohol }\end{array}$ \\
\hline Lipid absorption index (I.A.L) & $322,00 \pm 2$ & $334,67 \pm 4,51$ & $327,67 \pm 2,31$ \\
\hline Water retention capacity (C.R.A) & $323,67 \pm 1,53$ & $318,33 \pm 2,08$ & $313,67 \pm 0,58$ \\
\hline Apparent Density (D.A) & $0,28 \pm 0,01$ & $0,28 \pm 0,01$ & $0,27 \pm 0,01$ \\
\hline Swelling capacity (C.H) & $90,33 \pm 2,08$ & $80,33 \pm 0,58$ & $77,67 \pm 1,53$ \\
\hline Capacity of foam expansion (C.E.E) & $321,33 \pm 1,16$ & $312,33 \pm 2,52$ & $309 \pm 1$ \\
\hline Density of the foam (D.E) & $0,31 \pm 0,01$ & $0,31 \pm 0,02$ & $0,29 \pm 0,01$ \\
\hline Stability of the foam (E.E) & $8,47 \pm 0,15$ & $8,00 \pm 0,1$ & $8,2 \pm 0,53$ \\
\hline Emulsifying capacity (C.E.) & $51,67 \pm 2,08$ & $57,67 \pm 1,53$ & $51,33 \pm 1,15$ \\
\hline
\end{tabular}

Values correspond to mean of three replicates $+/$ - standard deviation

This ability of lipid-binding proteins is very important for the formulation of products for frying and for the retention of flavors. It also decreases the development of oxidative rancidity and consequently increases stability during storage $[3,6]$.

The data obtained in this study showed that the strong acid reduced I.A.L. of the protein concentrates, while the precipitation with alcohol increased it. The decrease in oil absorption capacity is believed to be due to the irreversible denaturation caused by extraction at $\mathrm{pH} 4.5$ that could have destroyed hydrophobic groups of proteins [10].

The ability to absorb water is considered a functional property of proteins, essential in viscous foods such as soups, sauces, dough and baked goods, products where a good protein-water interaction is required.

Foaming capacity and stability depend on two different sets of molecular properties. While the foaming capacity is affected by the rate of adsorption, flexibility and hydrophobicity, the stability depends on the rheological properties of the protein film. The protein of most foods is made up of mixtures of various molecular species; and therefore their foaming properties are determined by the interaction between the protein components at the interface $[3,6,10]$. They suggested that extractions with alcohol decrease (C.E.E). Alcohol may not be suitable in the food system that requires foaming like cake and ice cream [12].

The (C.E) was higher in the concentrate obtained with hydroalcoholic solutions with a percentage of $57.67 \%$, the other values are similar to those reported by Marrugo et al. (2012) [10]. This protein ability is particularly important in the manufacture of shaken products and emulsified sauces such as mayonnaise, frozen desserts and sausages.

The characteristics of an emulsion can be influenced by multiple factors, such as: type and geometry of the equipment used, intensity of energy used, rate of oil addition, temperature, $\mathrm{pH}$, ionic strength, presence of sugars and low surface agents molecular weight, oxygen exposure, type of fat (melting point) and concentration of soluble proteins $[1,3,17]$. This is why, if not carried out under standardized conditions, the same emulsion gives different results when studied by different researchers, explaining why the data published by different groups on the behavior of a protein as an emulsifier differ.

Next, the p-values for the analysis of variance are compared, which compares the three methods with respect to the functional properties. 
TABLE V. P values for the comparison of methods with respect to the functional properties

\begin{tabular}{|l|l|}
\hline Functional property & P value \\
\hline Lipid absorption index (I.A.L) & $0,000203^{*}$ \\
\hline Water retention capacity (C.R.A) & $3,79 \mathrm{E}-06^{*}$ \\
\hline Apparent Density (D.A) & 0,373 \\
\hline Swelling capacity (C.H) & $7,95 \mathrm{E}-06^{*}$ \\
\hline Capacity of foam expansion (C.E.E) & $2,15 \mathrm{E}-06^{*}$ \\
\hline Density of the foam (D.E) & 0,26 \\
\hline Stability of the foam (E.E) & $0,00332^{*}$ \\
\hline Emulsifying capacity (C.E.) & $0,0111^{*}$ \\
\hline
\end{tabular}

*: Significant difference $($ pvalue $<0,05)$

According to the analysis of variance, it is observed that there is significant difference in the average values of the different functional properties, with respect to the different methods, except for Apparent Density (D.A) and Density of the foam (D.E)

The following table shows the $\mathrm{p}$ values for the Tukey test, to verify which are the statistically differing methods, with respect to the functional properties.

Table VI. p values of the Tukey test

\begin{tabular}{|c|c|c|c|}
\hline Functional property & $\begin{array}{c}\text { Isoelectric point - } \\
\text { Hydroalcoholic } \\
\text { solutions }\end{array}$ & $\begin{array}{c}\text { Isoelectric point- } \\
\text { Isoelectric point and } \\
\text { alcohol }\end{array}$ & $\begin{array}{c}\text { Hydroalcoholic } \\
\text { solutions-Isoelectric } \\
\text { point and alcohol }\end{array}$ \\
\hline Lipid absorption index (I.A.L) & 0,0007439 & 0,7218714 & 0,0002901 \\
\hline Water retention capacity (C.R.A) & 0,0002059 & 0,0000028 & 0,002662 \\
\hline Swelling capacity (C.H) & 0,0000546 & 0,0000092 & 0,1755276 \\
\hline Capacity of foam expansion (C.E.E) & 0,0001 & 0,0000016 & 0,0023102 \\
\hline Stability of the foam (E.E) & 0,0068662 & 0,005753 & 0,9919387 \\
\hline Emulsifying capacity (C.E.) & 0,0901912 & 0,3426543 & 0,0091722 \\
\hline
\end{tabular}

The results show that in general there is significant difference between the different methods, the figures below show the behavior of the properties with respect to the different methods used; being 1: Isoelectric point , 2: Hydroalcoholic solutions and 3:Isoelectric point and alcohol.

IAL

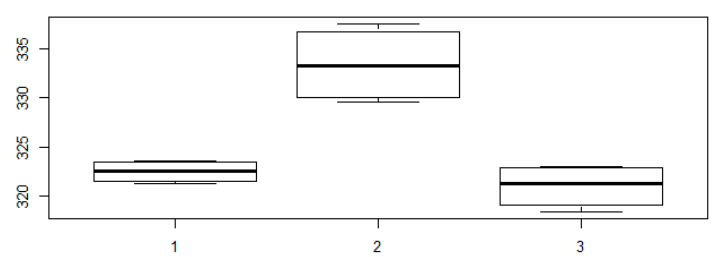

DA

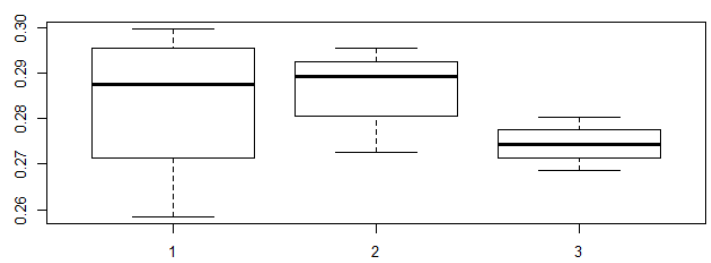

CRA

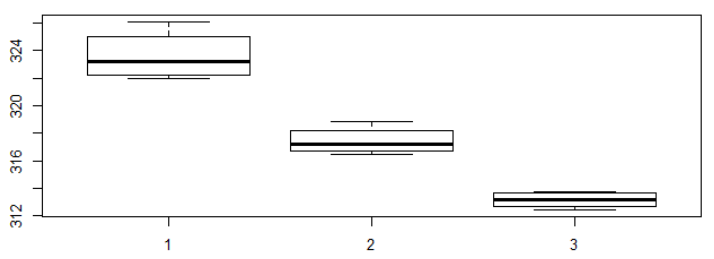

$\mathrm{CH}$

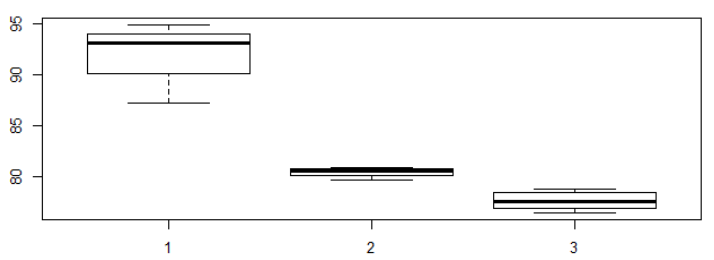


CEE

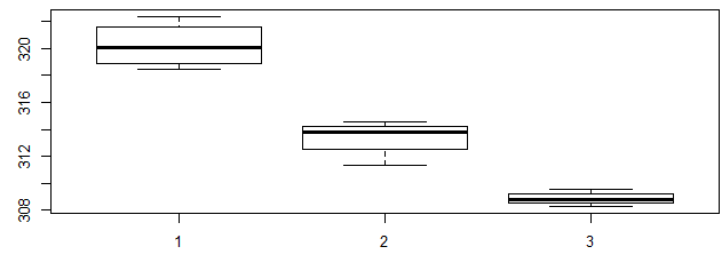

EE

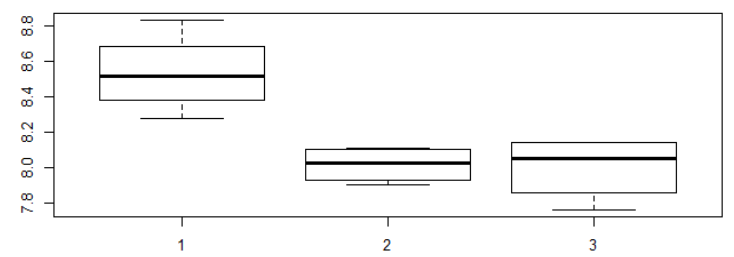

DE

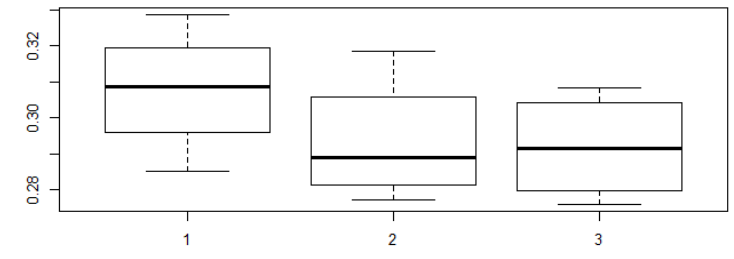

CE

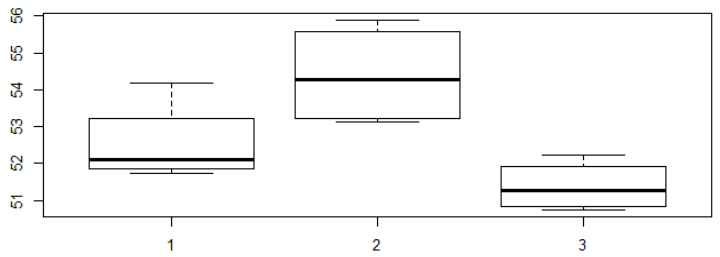

Fig. 1 Boxplot for the comparison of methods by the functional properties

The graphs show that in general it is the method 3 (Isoelectric point and alcohol) that presents on average the lowest levels in the different properties, which makes it more desirable in terms of nutrient loss.

In vitro digestibility of the Trupillo protein concentrate obtained by the isoelectric point, hydroalcoholic solutions and isoelectric point and alcohol

The in vitro digestibility of proteins of the protein concentrate of trupillo is shown in Table 7, is different for the samples obtained with different methods: 85,19 combined method (Isoelectric point and hydroalcoholic solutions), isoelectric point, 80,18 and solutions hydroalcoholic 77.35. These values were low when compared to Casein $(89,71 \%)$ and higher than those of other legumes such as Canavalia ensiformes (L) DC. (57.52\%). The digestibility for the concentrates obtained by the different methods is very high ranging between 77.35 and $85.19 \%$, indicating the high proportion of the protein absorbed from the ingested. The available protein is derived from the digestibility found.

Table VII. In vitro digestibility of protein concentrate

\begin{tabular}{|c|c|}
\hline Isoelectric point & $80,18 \pm 0,27$ \\
\hline Hydroalcoholic solutions & $77,35 \pm 1,11$ \\
\hline Isoelectric point and alcohol & $85,19 \pm 0,18$ \\
\hline
\end{tabular}

Values correspond to mean of three replicates $+/$ - standard deviation

\section{IV.CONCLUSIONS}

Of the protein concentrates obtained with different methods, the one with the highest values of protein content is the one obtained with the combined method, the same happens with the value of in vitro digestibility, showing a better correlation between the percentage of proteins, coefficient of digestibility And percent protein available. Due to the nutritional attributes presented by the trupillo concentrate: protein content, acceptable digestibility, give the opportunity to incorporate them in the design of new food products, improving its nutritional quality. Protein concentrates of trupe prepared by different methods varied in their functional properties, such as water / oil retention capacity, foaming capacity and emulsifying capacity. The study determined that the functional properties such as foaming ability of the protein prepared by isoelectric precipitation were the best in comparison to the others. It could be suitable for food systems that require foaming, such as cake and ice cream. The concentrate prepared by hydroalcoholic solutions has better lipid retention capacity. This can enable it to be effectively used for use in various food formulations such as weaning foods, dry mixes, baked goods, whipped cream and salad dressings, because of their oil binding capabilities. Studies on the application of protein concentrates of trupe in sausages need further study. Bacon concentrates can be a good source of protein for a variety of foodstuffs for consumers in developing countries. Their production could also add value to flour. 


\section{REFERENCES}

[1] J. Jaimes, J. Torres, and C. Severiche. "Analysis of the quality of a scalded meat product made with Prosopis juliflora flour," Ingenium., vol. 9, pp. 21-28, 2015.

[2] Y. Marrugo, C. Severiche, and J. Jaimes "Effect of Acetylation of Bean Starch Zaragoza (Phaseolus lunatus) Red Variety on its Functional Properties," International Journal of ChemTech Research., vol. 10, pp. 506-514, 2017.

[3] J. Jaimes, D. Restrepo, and D. Acevedo. "Preparación y determinación de las propiedades funcionales del concentrado proteico de trupillo (Prosopis juliflora)," Rev.Bio.Agro., vol. 12, pp. 144-152, 2014.

[4] Comisión del Codex Alimentarius, Alinorm. Programa Conjunto FAO / OMS sobre normas alimentarias. Directrices para la aplicación del Sistema de Análisis de Peligros y de los Puntos Críticos de Control (HACCP). Anexo al CAC/RCP 1-1969, Rev. 3 (1997)., Roma, Italia; 1995.

[5] Y. Marrugo, P. Montero, and M. Duran. "Nutritional Evaluation of Protein Concentrates of Phaseolus lunatus and Vigna unguiculata," Technological Information., vol. 27, pp. 107-114, 2016.

[6] J. Torres, K. González, D. Acevedo, and J. Jaimes. "Efecto de la utilización de harina de Lens culinaris como extensor en las características físicas y aceptabilidad de una salchicha," Tecnura., vol. 20, pp. 15-28, 2016.

[7] V. Almeida, B. Rocha, J. Pfister, R. Medeiros, F. Riet-Correa, H. Chaves, G. Silva, and F. Mendonça. "Spontaneous poisoning by Prosopis juliflora (Leguminosae) in sheep," Pesquisa Veterinária Brasileira., vol. 37, pp. 110-114, 2017.

[8] Y. Marrugo, E. Torregroza, and P. Montero. "Nutritional potential of three Zaragoza bean (Phaseolus lunatus 1) cultivars and their in vitro digestibility estimation,” Journal of the Faculty of Agronomy., vol. 29, pp. 314 - 326, 2012.

[9] I. Baldiris-Navarro, Y. Marrugo-Ligardo, C. Severiche-Sierra, J. Jaimes-Morales, W. Fong-Silva, L.Vargas-Ortiz, E. Bedoya-Marrugo, H. Cohen-Padilla. "Delayed Organoleptic Maturation of Tomato Variety Milano (Lycopersicum esculentum Mill) Using Giberelina", International Journal of ChemTech Research., vol. 10, pp. 1032-1037, 2017.

[10] Y. Marrugo, P. Montero, and M. Duran. "Functional properties of protein concentrates of Phaseolus lunatus and Vigna unguiculata," Vitae., vol. 19, pp. S403-S405, 2012.

[11] Y. Marrugo, C. Severiche, and J. Jaimes. "Development of a Food Product Type Based Sauce Egg plant (Solanum melongena) ," International Journal of ChemTech Research., vol. 10, pp. 567-571, 2017.

[12] Y. Marrugo, E. Torregroza, and P. Montero. "Elaboration of a pate-like food using as a flour extender of the Zaragoza bean Phaseolus lunatus,”@Limentech.,vol.5,pp. 45-48,2007.

[13] C. Severiche, M. Castillo, and R. Acevedo. Manual de Métodos Analíticos para la Determinación de Parámetros Fisicoquímicos Básicos en Aguas. Editado por la Fundación Universitaria Andaluza Inca Garcilaso para eumed.net. 1 Ed. Malaga (España), 2013. www.eumed.net/libros-gratis/2013a/1326/1326.pdf

[14] L. Bohnenberger, S. Gomes, S. Coelho, S. Machado, and W. Boscolo. "Concentrado proteico de folhas de mandioca na alimentação de tilápias-do-nilo na fase de reversão sexual,” Revista Brasileira de Zootecnia., vol. 39, 1169-1174, 2010.

[15] J. Vioque, A. Clemente, J. Pedroche, M. Yust, and F. Millán. “Obtención y aplicaciones de hidrolizados protéicos,”. Grasas y Aceites., vol. 52, 132-136, 2001

[16] H. Wu, Q. Wang, T. Ma, and J. Ren. "Comparative studies on the functional properties of various protein concentrate preparations of peanut protein,” Food Res Int., vol. 42, 343-348, 2009.

[17] Y. Marrugo, E. Torregroza, R. Coneo, P. Villa, and P. Montero. "Obtaining a high protein drink from the Zaragoza bean (Phaseolus lunatus) white variety,”@Limentech., vol. 5, pp.63-68, 2007.

[18] P. Miranda, Y. Marrugo, and P. Montero. "Functional Characterization of Bean Zaragoza Starch (Phaseolus lunatus 1) and Quantification of the Resistant Starch,” TecnoLógicas., vol. 30, pp. 17-32, 2013.

[19] AOAC. (Association Of Official Analytical Chemists). Official methods of analysis. 15. Ed. Washington: AOAC, 1990.

[20] Y. Sánchez, and M. Ramírez. "Tratamientos pregerminativos en semillas de Leucaena leucocephala (Lam.) de Wit. y Prosopis juliflora (Sw.) DC,” Revista de la Facultad de Agronomía., vol. 23, pp. 257-272, 2006.

[21] M. Chaparro, S. Zaghloul, P. Holck, and J. Dobbs. "Food insecurity prevalence among college students at the University of Hawai'i at Mānoa," Public Health Nutr., vol. 12, pp. 2097-103, 2009. 